\title{
Effect of magnesium on nerve conduction velocity during regular dialysis treatment
}

\author{
LAURA W. Fleming, J. A. R. LENMAN, AND W. K. STEWART \\ From the Department of Medicine, Dundee University, \\ and the Renal Unit, Maryfield Hospital, Dundee
}

SUMMARY Serial nerve conduction velocities in the peroneal and ulnar nerves have been measuredo in 10 patients on regular dialysis treatment over a three year period. Each patient alternated be $\frac{\overline{\bar{s}}}{\bar{s}}$ tween phases on dialysis with magnesium-containing dialysate $(1.5-1.7 \mathrm{~m}$-equiv/l.) and phases onळ 'magnesium-free' dialysate $(0.2 \mathrm{~m}$-equiv/1.). Plasma magnesium concentrations were high both pre-ڤ and post-dialysis during magnesium-containing dialysis, and normal to low on magnesium-freedialysis. All patients had defects in nerve conduction, mainly asymptomatic. Increases in nerve- conduction velocity coincided with magnesium-free dialysis, and decreases occurred when the $\bar{\sigma}^{-}$ patients reverted to magnesium-containing dialysate. The significance of the correlation by the sign test was $P<0.0005$. It is concluded that extracellular magnesium levels can influence the rate of nerve conduction in vivo.

The observation of persistent hypermagnesaemia in our patients on maintenance dialysis prompted us to consider dialysing them with less magnesium in the dialysis-fluid. This step was taken in the hope of lowering the mean plasma magnesium concentration.

Magnesium concentrations have often appeared to influence the transmission of impulses across nerve membranes (for example, Frankenhaeuser and Meves, 1958) and magnesium has been implicated in the adenosine triphosphatase (ATP-ase) enzyme system which is intimately connected with the changes that occur in nerve membranes during depolarization (Abood, 1966). Most studies to date on the effect of magnesium on the neuromuscular system have been in vitro (for example, Frankenhaeuser and Meves, 1958; Katz and Miledi, 1965) and application to the intact animal situation, let alone to clinically observed variations, has been assumed rather than demonstrated. Although the effect of magnesium on neuromuscular transmission is well established, there is relatively little information about its effect on conduction of the nerve impulse along the axon.

Neuropathy is common in patients on maintenance dialysis (Preswick and Jeremy, 1964) and it was therefore decided to measure serial nerve conduction velocity rates concurrently wiकh the alterations in dialysis-fluid magnesium content.

A preliminary account of our early studies has been given (Stewart, Fleming, Anderson, Le⿳亠े⿵冂丶 man and Jamieson, 1967) and this report $\mathrm{N}^{-}$ extends our original findings.

\section{METHODS}

haEmodialysis TREATMEnT Patients were dialysed twice weekly, for 10 to 12 hours in each dialysis $=$ session, using Kolff-Travenol disposable twin-coil 윽 dialysers. Magnesium derived from the dialysate $\overrightarrow{ }$ concentrate (Ilford, Ltd) was present in the dialysis fluid as originally used at a concentration of $1.50 \%$ m-equiv/l. (magnesium-plus). When concentrate without magnesium was used (magnesium-free), only the small amount of magnesium in Dundee tap 3 water was present; serial estimations of this ranged from 0.15 to $0 \cdot 17 \mathrm{~m}$-equiv/1. Initially it was the policy of the Dundee Renal Unit, as in other dialysis centres, to dialyse with a concentration of $4 \mathrm{~m}$-equiv/ 1. calcium in the dialysate ( $\mathrm{Ca}-4$ solution) but hyper $\frac{D}{O}$ calcaemia became apparent, and the patients were all transferred on to dialysis with fluid containing $N$ $3 \mathrm{~m}$-equiv/1. (Ca-3 solution). New patients entering the programme in 1968 or subsequently were 
TABLE 1

NUMBER OF MONTHS ON EACH PHASE OF RDT

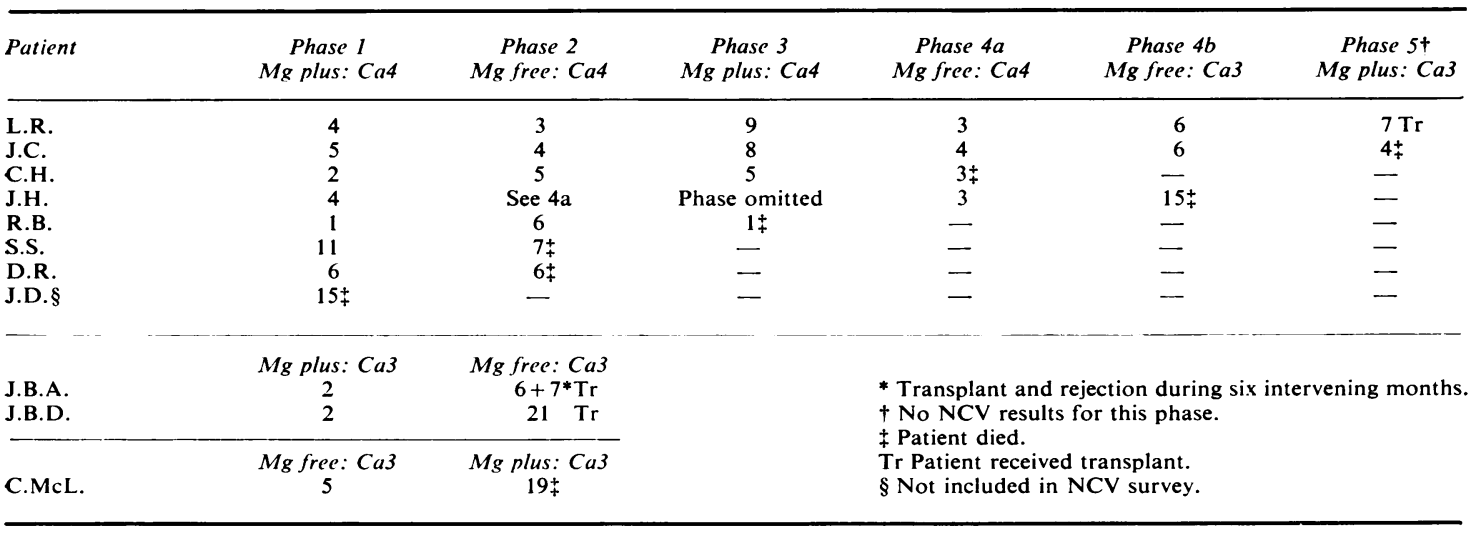

dialysed throughout with Ca-3 solution. The only other change in the dialysis-fluid was an increase in the sodium concentration from $130 \cdot 0$ to $131 \cdot 5(\mathrm{Ca}-4$ solution) or from 131.0 to 132.5 (Ca-3 solution) m-equiv/l. when magnesium was absent.

All patients were placed on an $80 \mathrm{~g}$ protein diet, supplying approximately 2,000 Calories. No aluminium-containing antacids were given throughout the course of the investigation. Vitamin supplements including vitamin $\mathrm{C}$ and folic acid were given.

SAMPLES Ten patients entered the investigation programme (Table 1). Venous blood samples were taken immediately pre-dialysis and arterial samples immediately post-dialysis. Plasma magnesium concentrations were measured by atomic absorption spectrophotometry with the Zeiss FA-2 attachment (Fleming and Stewart, 1966).

MEASUREMENT OF NERVE CONDUCTION VELOCITY Initially nerve conduction velocities (NCV) were measured both pre- and post-dialysis. Latterly only post-dialysis measurements were made, usually after an overnight dialysis, but in a few instances on the morning of the day following daytime dialysis. Motor nerve conduction velocity (NCV) was measured in the ulnar (arms) and common peroneal (legs) nerves by applying rectangular electrical pulses through an isolation transformer at different sites along their course and recording evoked potentials by surface electrodes from the abductor digiti minimi and the extensor digitorum brevis muscles (Lenman and Ritchie, 1970). By subtracting the result for the shorter distance from that for the longer distance an estimate of the nerve conduction velocity is obtained which does not include the time taken by the impulses to cross the neuromuscular junction. Sensory conduction velocity was also measured on the distal portion of the ulnar nerves by recording action potentials from the nerve at the wrist after stimulation through ring electrodes around the fifth finger. In every case latent periods were measured on photographed oscillograph traces. Room temperatures were recorded for each measurement and, after the first three months of the investigation, skin temperatures were also recorded. Measurements were made in warm surroundings and extremities were warmed if skin temperatures locally were less than $30^{\circ} \mathrm{C}$.

\section{RESULTS}

PlASMA MAGNESIUM CHANGES During dialysis with magnesium-free dialysis-fluid, the new lower plasma magnesium level (Fig. 1) was established after only two or three dialyses and thereafter remained fairly constant. On reversion to magnesium-plus dialysis the plasma concentrations immediately increased again. Post-dialysis magnesium concentrations were lower than pre-dialysis concentrations both in magnesium-plus and magnesium-free phases, but the extent of the decrease was less when magnesium was present in the dialysis-fluid. The hypermagnesaemia of the magnesium-plus phase was consistent in all patients, ranging from 2.40 to 3.40 m-equiv/l., with no difference between early and late phases in those with more than one phase on each fluid. The striking increase observed in patient J.B.D. was found to be due 


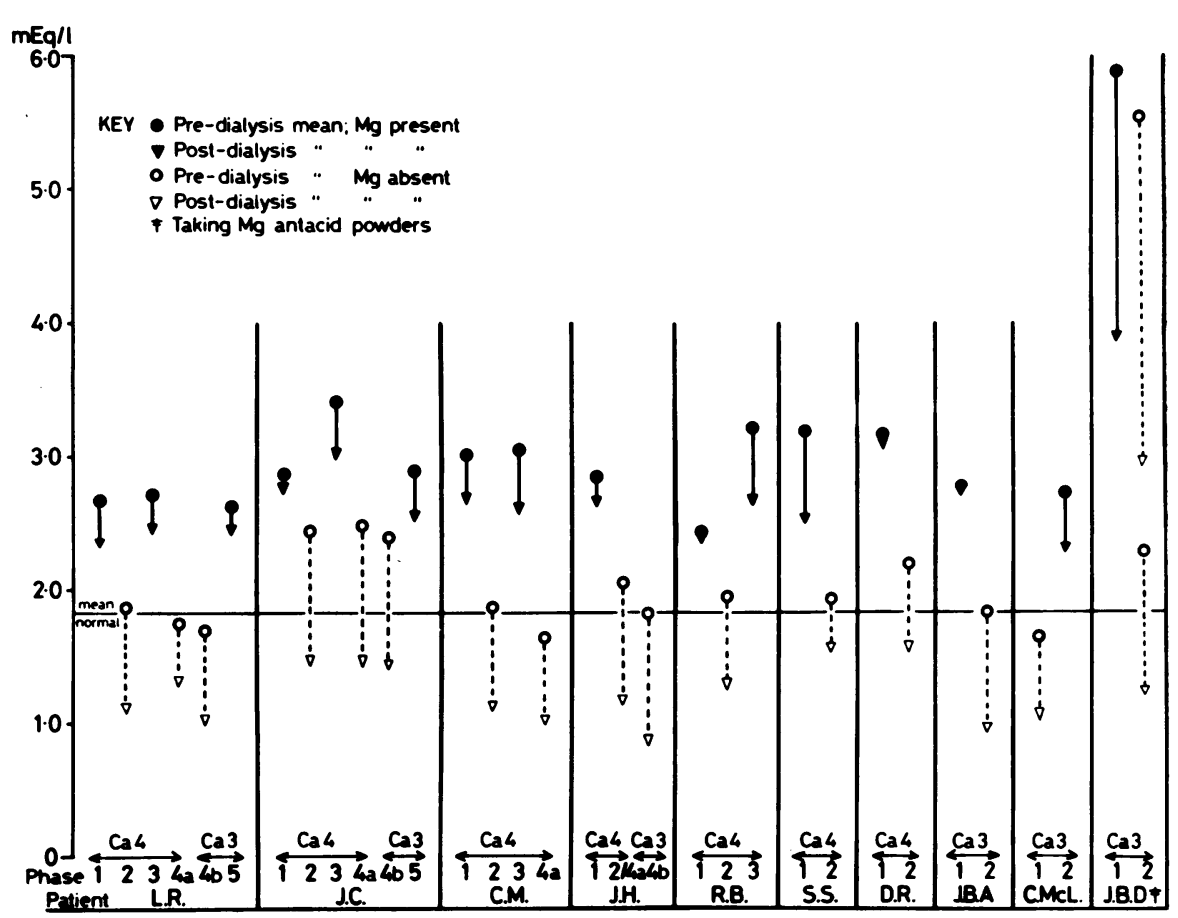

FIG. 1. Mean plasma magnesium concentrations during $R D T$.

to his ingestion of antacids composed mainly of magnesium salts, such that his daily magnesium intake approached $60 \mathrm{~m}$-equiv. This fact became apparent when his plasma magnesium remained high after changing to magnesium-free dialysis, but within two weeks of stopping the powders, his plasma magnesium concentration had reverted to levels comparable with the other patients on regular dialysis treatment (RDT). Generally, post-dialysis plasma magnesium on magnesium-free dialysis was seldom lower than $0.90 \mathrm{~m}$-equiv/l. and most often more than 1.00 m-equiv/l.

OTHER PLASMA CHANGeS There were no systematic differences between the magnesium-plus and magnesium-free phases as far as the plasma concentrations of calcium, phosphate, sodium, potassium, bicarbonate, urea, and creatinine were concerned.

NERVE CONDUCTION VELOCITY CHANGES Baseline neuropathy Nerve conduction velocities were defined as normal, borderline, or abnormal according to the following criteria: for mogos nerves in the legs, borderline was taken $40 \pm 4 \mathrm{~m} / \mathrm{sec}$, for motor nerves in the armị $\mathrm{s}$ borderline was taken as $45 \pm 4 \mathrm{~m} / \mathrm{sec}$ and for sensory nerves in the hands, borderline wa: taken as $36 \pm 4 \mathrm{~m} / \mathrm{sec}$. The abnormal and normas categories included values either below or above these levels respectively.

Baseline measurements, assessed on these criteria, confirmed the existence of subclinicas neuropathy in all patients (Table 2). None of the patients had normal motor velocities in the lege The baseline results for five additional patients. not included in the long-term investigation, arê also shown (additional group). Patient J.D. dieç before phase 2 began and the last four com 3 . menced RDT too late to be included in the maid survey, but their conduction velocities are of interest in that the last four patients were dialyse $\$$ only with magnesium-free solution, and patients A.H. and D.H. in particular showed more. normality than the patients dialysed for a coms parable period of time with magnesium present although the motor nerve deterioration in th: 
TABLE 2

ASSESSMENT OF BASELINE NERVE CONDUCTION VELOCITY* IN PATIENTS ON RDT

\begin{tabular}{|c|c|c|c|c|c|c|}
\hline \multirow[t]{2}{*}{ Patient } & \multirow[t]{2}{*}{ Sex } & \multirow{2}{*}{$\begin{array}{c}\text { Age } \\
(y r)\end{array}$} & \multirow{2}{*}{$\begin{array}{l}\text { No. of } \\
\text { dialyses§ }\end{array}$} & \multicolumn{2}{|c|}{ Motor } & \multirow[t]{2}{*}{ Sensory } \\
\hline & & & & Legs & Arms & \\
\hline $\begin{array}{l}\text { C.M. } \\
\text { L.R. }\end{array}$ & $\begin{array}{l}\mathbf{F} \\
\mathbf{F}\end{array}$ & $\begin{array}{l}18 \\
13\end{array}$ & $\begin{array}{l}22 \\
38\end{array}$ & $\begin{array}{l}\text { Borderline } \\
\text { Borderline }\end{array}$ & $\begin{array}{l}\text { Normal } \\
\text { L Borderline, } \\
\text { R Normal }\end{array}$ & $\begin{array}{l}\text { Normal } \\
\text { Borderline }\end{array}$ \\
\hline $\begin{array}{l}\text { J.C. } \\
\text { D.R. } \\
\text { S.S. }\end{array}$ & $\begin{array}{l}\mathbf{M} \\
\mathbf{M} \\
\mathbf{M}\end{array}$ & $\begin{array}{l}23 \\
48 \\
26\end{array}$ & $\begin{array}{l}42 \\
50 \\
88\end{array}$ & $\begin{array}{l}\text { Borderline } \\
\text { Abnormal } \\
\text { Abnormal }\end{array}$ & $\begin{array}{l}\text { Normal } \\
\text { Borderline } \\
\text { L Abnormal, } \\
\text { R Borderline }\end{array}$ & $\begin{array}{l}\text { Normal } \\
\text { Abnormal } \\
\text { Abnormal }\end{array}$ \\
\hline $\begin{array}{l}\text { J.H. } \\
\text { R.B. } \\
\text { J.B.A. } \\
\text { J.B.D. } \\
\text { C.McL. }\end{array}$ & $\begin{array}{l}\mathbf{F} \\
\mathbf{M} \\
\mathbf{M} \\
\mathbf{M} \\
\mathbf{F}\end{array}$ & $\begin{array}{l}30 \\
30 \\
22 \\
33 \\
56\end{array}$ & $\begin{array}{c}56 \\
33 \\
27 \\
16 \\
0+\end{array}$ & $\begin{array}{l}\text { Abnormal } \\
\text { Abnormal } \\
\text { Borderline } \\
\text { Abnormal } \\
\text { Borderline }\end{array}$ & $\begin{array}{l}\text { Borderline } \\
\text { Borderline } \\
\text { Borderline } \\
\text { Borderline } \\
\text { Normal }\end{array}$ & $\begin{array}{l}\text { Borderline } \\
\text { Abnormal } \\
\text { Normal } \\
\text { Borderline } \\
\text { Normal }\end{array}$ \\
\hline $\begin{array}{l}\text { Addition } \\
\text { J.D. } \\
\text { A.H. } \\
\text { D.H. } \\
\text { J.Da. } \\
\text { J.S. }\end{array}$ & $\begin{array}{l}p \\
F \\
\text { F } \\
\text { F } \\
\text { F } \\
\text { M }\end{array}$ & $\begin{array}{l}35 \\
29 \\
40 \\
51 \\
55\end{array}$ & $\begin{array}{r}147 \\
57 \pm \\
97 \pm \\
2 \pm \\
4 \div\end{array}$ & $\begin{array}{l}\text { Abnormal } \\
\text { Borderline } \\
\text { Borderline } \\
\text { Borderline } \\
\text { Borderline }\end{array}$ & $\begin{array}{l}\text { Borderline } \\
\text { Normal } \\
\text { Normal } \\
\text { Normal } \\
\text { Normal }\end{array}$ & $\begin{array}{l}\text { Borderline } \\
\text { Borderline } \\
\text { Normal } \\
\text { Normal } \\
\text { Borderline }\end{array}$ \\
\hline
\end{tabular}

* Assessed on the mean NCV over the Mg-plus (phase 1) period.

+ Assessed on one result only, immediately before RDT.

$\ddagger$ Assessed on one result only, after the specified number of dialyses (Mg-free).

$\S$ At time of first dialysis without magnesium (end of phase 1) unless otherwise specified by symbol.

At time of first dialysis on RDT.

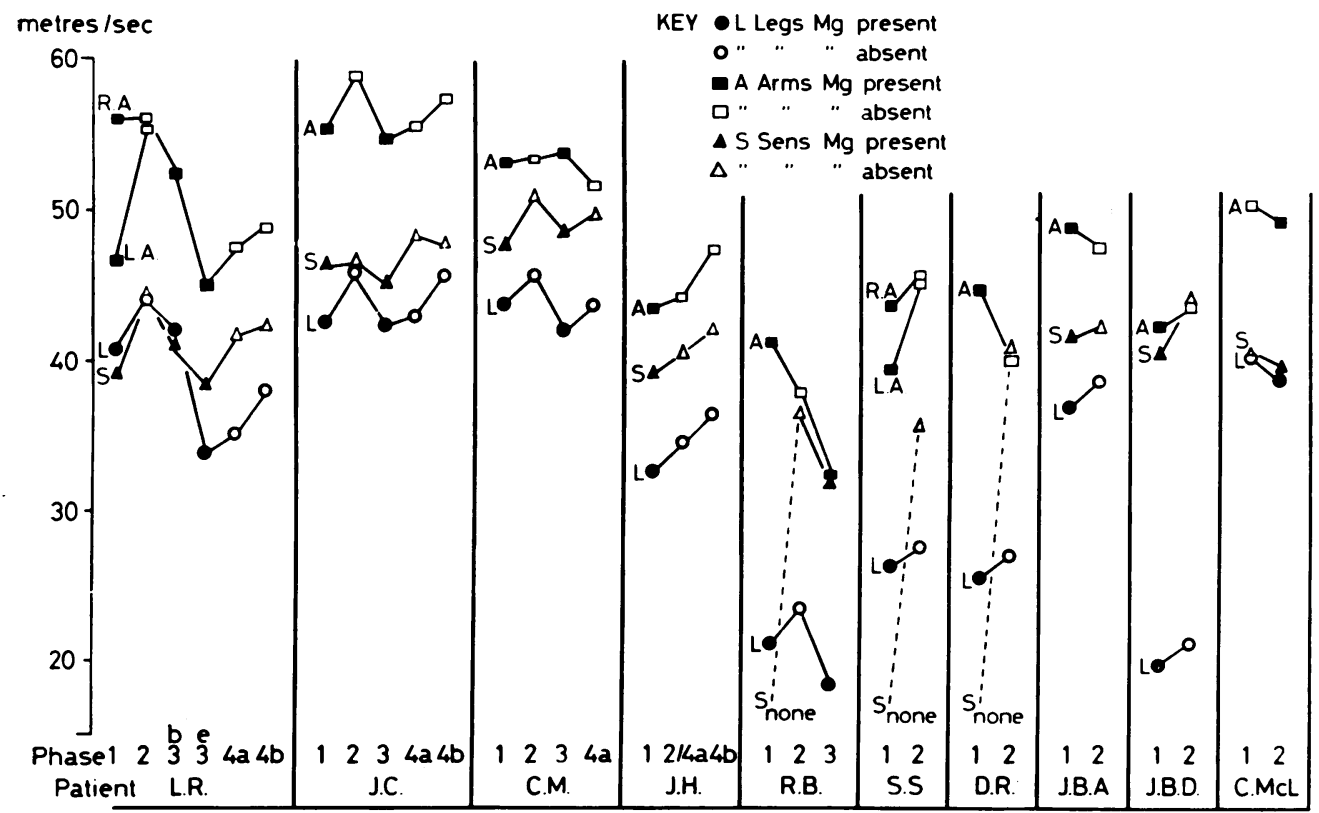

FIG. 2. Mean nerve conduction velocities during RDT. 
legs was still apparent. Only three of the 10 surveyed patients had normal motor velocities in the arms and only four had normal sensory conductions, but the four later patients in the additional group, dialysed only with magnesiumfree solutions, had normal motor velocities in the arms and two also had normal sensory conduction.

Effect of magnesium changes The overall mean velocities for each phase are shown in chronological order for legs (L), arms (A), and sensory (S) respectively (Fig. 2). In two patients (L.R. and S.S.) the velocities in the two arms differed to such an extent that the mean values are shown separately. In all other patients the mean values are for both right and left limbs. It can be seent (Fig. 2) that with only four exceptions, the oper? symbols representing magnesium-free dialysesp are higher than the filled-in symbols for each nerve. In other words an improvement in nerven conduction velocity was found to coincide witho dialysis without magnesium, and a slowing in velocities occurred on returning to magnesiums containing dialysis. Patient C.McL. was the onlye patient in this series to begin with magnesium? free dialysis.

The mean values and standard deviations for the early part of the investigation, when $\mathrm{Ca}-\frac{2}{2}$ fluid was used, are shown (Table 3), along with the number of estimations in each phase. The decrease in conduction velocity was so great in

TABLE 3

MEAN NERVE CONDUCTION VELOCITIES (M/SEC) IN PATIENTS ON RDT, COMPARING PRESENCE AND ABSENCE OF MAGNESIUM IN DIALYSIS FLUID CONTAINING 4 M-EQUIV/L. CALCIUM

\begin{tabular}{|c|c|c|c|c|c|c|c|c|c|c|c|c|}
\hline \multirow[t]{3}{*}{ Patient } & \multirow[t]{3}{*}{ Nerve } & \multirow[t]{3}{*}{$\begin{array}{l}\text { Baseline } \\
\text { group }\end{array}$} & \multicolumn{2}{|c|}{$\begin{array}{c}\text { Phase } 1 \\
M g \text { plus: } \mathrm{Ca} 4\end{array}$} & \multicolumn{2}{|c|}{$\begin{array}{c}\text { Phase } 2 \\
M g \text { free: } \mathrm{Ca} 4\end{array}$} & \multicolumn{4}{|c|}{$\begin{array}{c}\text { Phase } 3 \\
\text { Mg plus: } \text { Ca4 }\end{array}$} & \multicolumn{2}{|c|}{$\begin{array}{c}\text { Phase } 4^{*} \\
\text { Mg free: } \mathrm{Ca}{ }^{\circ} \bar{O}\end{array}$} \\
\hline & & & \multirow{2}{*}{$\begin{array}{l}\text { No. of } \\
\text { est. }\end{array}$} & \multirow{2}{*}{$\begin{array}{l}\text { Mean } \\
\text { NCV }\end{array}$} & \multirow{2}{*}{$\begin{array}{l}\text { No. of } \\
\text { est. }\end{array}$} & \multirow{2}{*}{$\begin{array}{l}\text { Mean } \\
\text { NCV }\end{array}$} & \multicolumn{2}{|c|}{ Beginning } & \multicolumn{2}{|r|}{ End } & \multirow{2}{*}{$\begin{array}{l}\text { No. of } \\
\text { est. }\end{array}$} & \multirow{2}{*}{ 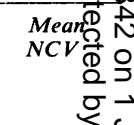 } \\
\hline & & & & & & & $\begin{array}{l}\text { No. of } \\
\text { est. }\end{array}$ & $\begin{array}{l}\text { Mean } \\
\text { NCV }\end{array}$ & $\begin{array}{l}\text { No. of } \\
\text { est. }\end{array}$ & $\begin{array}{l}\text { Mean } \\
\text { NCV }\end{array}$ & & \\
\hline L.R. & $\begin{array}{l}\text { Legs } \\
\text { Arms } \\
\text { Arms } \\
\text { Sens }\end{array}$ & $\begin{array}{l}\mathbf{B} \\
\mathbf{N} \\
\mathbf{B} \\
\mathbf{B}\end{array}$ & $\begin{array}{l}6 \\
3 \\
3 \\
6\end{array}$ & $\begin{array}{l}40 \cdot 7 \pm 2 \cdot 8 \\
56 \cdot 0 \pm 4 \cdot 2 \\
46 \cdot 6 \pm 2 \cdot 0 \\
39 \cdot 1 \pm 3 \cdot 2\end{array}$ & $\begin{array}{r}20 \\
12 \\
9 \\
21\end{array}$ & $\begin{array}{l}44 \cdot 1 \pm 3 \cdot 3 \\
56 \cdot 1 \pm 4 \cdot 8 \\
55 \cdot 4 \pm 4 \cdot 5 \\
44 \cdot 5 \pm 4 \cdot 5\end{array}$ & $\begin{array}{r}15 \\
8 \\
9\end{array}$ & $\begin{array}{l}42 \cdot 1 \pm 2 \cdot 4 \\
52 \cdot 4 \pm 2 \cdot 6 \\
41 \cdot 0 \pm 3 \cdot 1\end{array}$ & $\begin{array}{l}2 \\
4 \\
4\end{array}$ & $\begin{array}{l}33.8 \pm 0.6 \\
45.0 \pm 4 \cdot 1 \\
38.4 \pm 1.4\end{array}$ & $\begin{array}{l}18 \\
29 \\
32\end{array}$ & 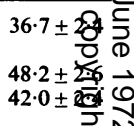 \\
\hline J.C. & $\begin{array}{l}\text { Legs } \\
\text { Arms } \\
\text { Sens }\end{array}$ & $\begin{array}{l}\mathbf{B} \\
\mathbf{N} \\
\mathbf{N}\end{array}$ & $\begin{array}{r}10 \\
10 \\
7\end{array}$ & $\begin{array}{l}42 \cdot 6 \pm 3 \cdot 6 \\
55 \cdot 5 \pm 5 \cdot 3 \\
46 \cdot 3 \pm 3 \cdot 9\end{array}$ & $\begin{array}{l}10 \\
16 \\
15\end{array}$ & $\begin{array}{l}45 \cdot 9 \pm 3 \cdot 1 \\
58 \cdot 9 \pm 5 \cdot 3 \\
46 \cdot 6 \pm 2 \cdot 6\end{array}$ & & $\begin{array}{l}11 \\
20 \\
20\end{array}$ & $\begin{array}{l}42 \cdot 4 \pm 2 \cdot 8 \\
54 \cdot 8 \pm 4 \cdot 1 \\
45 \cdot 2 \pm 2 \cdot 7\end{array}$ & & $\begin{array}{l}14 \\
31 \\
32\end{array}$ & $\begin{array}{l}44 \cdot 8 \pm 2.6 \\
56 \cdot 6 \pm 4 \cdot 7 \\
48 \cdot 0 \pm 3.4\end{array}$ \\
\hline C.McL. & $\begin{array}{l}\text { Legs } \\
\text { Arms } \\
\text { Sens }\end{array}$ & $\begin{array}{l}\mathbf{B} \\
\mathbf{N} \\
\mathbf{N}\end{array}$ & $\begin{array}{r}18 \\
9 \\
9\end{array}$ & $\begin{array}{l}43 \cdot 8 \pm 2 \cdot 9 \\
53 \cdot 3 \pm 5 \cdot 3 \\
47 \cdot 8 \pm 4 \cdot 6\end{array}$ & $\begin{array}{l}30 \\
19 \\
18\end{array}$ & $\begin{array}{l}45 \cdot 7 \pm 5 \cdot 4 \\
53 \cdot 5 \pm 4 \cdot 4 \\
51 \cdot 0 \pm 5 \cdot 7\end{array}$ & & $\begin{array}{l}12 \\
10 \\
11\end{array}$ & $\begin{array}{l}42 \cdot 1 \pm 1 \cdot 6 \\
53 \cdot 9 \pm 3 \cdot 1 \\
48 \cdot 6 \pm 3 \cdot 2\end{array}$ & & $\begin{array}{l}3 \\
2 \\
2\end{array}$ & 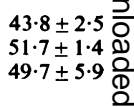 \\
\hline R.B. & $\begin{array}{l}\text { Legs } \\
\text { Arms } \\
\text { Sens }\end{array}$ & $\begin{array}{l}\mathbf{A} \\
\mathbf{B} \\
\mathbf{A}\end{array}$ & $\begin{array}{l}6 \\
6 \\
6\end{array}$ & $\begin{array}{c}21 \cdot 1 \pm 3 \cdot 4 \\
41 \cdot 3 \pm 3 \cdot 3 \\
\text { None evoked }\end{array}$ & $\begin{array}{r}10 \\
16 \\
8\end{array}$ & $\begin{array}{l}23 \cdot 5 \pm 2 \cdot 8 \\
37 \cdot 9 \pm 3 \cdot 3 \\
36 \cdot 5 \pm 1 \cdot 8\end{array}$ & & $\begin{array}{l}1 \\
4 \\
2\end{array}$ & $\begin{array}{l}18 \cdot 3 \\
32 \cdot 4 \pm 1 \cdot 1 \\
32 \cdot 0 \pm 0\end{array}$ & & & 윽 \\
\hline J.H. & $\begin{array}{l}\text { Legs } \\
\text { Arms } \\
\text { Sens }\end{array}$ & $\begin{array}{l}\mathbf{A} \\
\mathbf{B} \\
\mathbf{B}\end{array}$ & $\begin{array}{r}6 \\
15 \\
14\end{array}$ & $\begin{array}{l}32 \cdot 7 \pm 4 \cdot 2 \\
43 \cdot 6+2 \cdot 7 \\
39 \cdot 2 \pm 4 \cdot 2\end{array}$ & Phase & e omitted & & Phas & e omitted & & $\begin{array}{l}19 \\
35 \\
35\end{array}$ & $\begin{array}{l}35 \cdot 7 \pm 2 \cdot 8 \stackrel{\text { 亭 }}{4} \\
46 \cdot 0 \pm 3 \cdot 1 \stackrel{\text {. }}{41 \cdot 4 \pm 2 \cdot 8}\end{array}$ \\
\hline S.S. & $\begin{array}{l}\text { Legs } \\
\text { Arms } \\
\text { Arms } \\
\text { Sens }\end{array}$ & $\begin{array}{l}\mathbf{A} \\
\mathbf{B} \\
\mathbf{A} \\
\mathbf{A}\end{array}$ & $\begin{array}{l}8 \\
4 \\
4 \\
8\end{array}$ & $\begin{array}{c}26 \cdot 4 \pm 2 \cdot 7 \\
43 \cdot 7 \pm 3 \cdot 7 \\
39 \cdot 5 \pm 2 \cdot 6 \\
\text { None evoked }\end{array}$ & $\begin{array}{l}7 \\
4 \\
2 \\
4\end{array}$ & $\begin{array}{l}27 \cdot 6 \pm 2 \cdot 6 \\
45 \cdot 7 \pm 1 \cdot 4 \\
45 \cdot 2 \pm 0 \cdot 9 \\
35 \cdot 7 \pm 4 \cdot 6\end{array}$ & & & & & & 음 \\
\hline D.R. & $\begin{array}{l}\text { Legs } \\
\text { Arms } \\
\text { Sens }\end{array}$ & $\begin{array}{l}\mathbf{A} \\
\mathbf{B} \\
\mathbf{A}\end{array}$ & $\begin{array}{l}2 \\
4 \\
4\end{array}$ & $\begin{array}{c}25 \cdot 7 \pm 3 \cdot 5 \\
44 \cdot 8 \pm 4 \cdot 0 \\
\text { None evoked }\end{array}$ & $\begin{array}{r}7 \\
12 \\
2\end{array}$ & $\begin{array}{l}27 \cdot 0 \pm 4 \cdot 3 \\
40 \cdot 2 \pm 3 \cdot 3 \\
40 \cdot 9 \pm 1 \cdot 2\end{array}$ & & & & & & $\frac{3}{3}$ \\
\hline $\begin{array}{l}\text { E.C. } \\
\text { Twin } \\
\text { of J.C. }\end{array}$ & $\begin{array}{l}\text { Legs } \\
\text { Arms } \\
\text { Sens }\end{array}$ & $\begin{array}{l}\mathbf{N} \\
\mathbf{N} \\
\mathbf{N}\end{array}$ & $\begin{array}{l}6 \\
6 \\
5\end{array}$ & $\begin{array}{c}\text { For compariso } \\
55.6 \pm 3.0 \\
63 \cdot 2 \pm 3.4 \\
46.0 \pm 4.6\end{array}$ & & & & & & & & N \\
\hline & & & $f t$ & atients. & & & & & & & & $\frac{\sigma}{\frac{\sigma}{2}}$ \\
\hline
\end{tabular}


TABLE 4

MEAN NERVE CONDUCTION VELOCITIES (M/SEC) IN PATIENTS ON RDT, COMPARING THE PRESENCE AND ABSENCE OF MAGNESIUM IN DIALYSIS-FLUID CONTAINING 3 M-EQUIV/L. CALCIUM

\begin{tabular}{|c|c|c|c|c|c|c|c|c|c|}
\hline \multirow[t]{2}{*}{ Patient } & \multirow[t]{2}{*}{ Nerve } & \multirow[t]{2}{*}{$\begin{array}{l}\text { Baseline } \\
\text { group }\end{array}$} & \multicolumn{2}{|c|}{$\begin{array}{c}\text { Phase } 1 \\
\text { Mg plus: Ca3 }\end{array}$} & \multicolumn{2}{|c|}{$\begin{array}{c}\text { Phase } 2 \\
\mathrm{Mg} \text { free: } \mathrm{Ca} 3\end{array}$} & \multirow[t]{2}{*}{$\begin{array}{c}\text { Difference } \\
\Delta\end{array}$} & \multicolumn{2}{|c|}{$\begin{array}{c}\text { Significance } \\
P\end{array}$} \\
\hline & & & $\begin{array}{l}\text { No. of } \\
\text { est. }\end{array}$ & $\begin{array}{c}\text { Mean } \\
\text { NCV* }\end{array}$ & $\begin{array}{l}\text { No. of } \\
\text { est. }\end{array}$ & $\begin{array}{l}\text { Mean } \\
\text { NCV* }\end{array}$ & & & \\
\hline J.B.A. & $\begin{array}{l}\text { Legs } \\
\text { Arms } \\
\text { Sens }\end{array}$ & $\begin{array}{l}\mathbf{B} \\
\mathbf{N}\end{array}$ & $\begin{array}{r}10 \\
4 \\
7 \\
4 \\
8 \\
4\end{array}$ & $\begin{array}{l}37 \cdot 0 \pm 2 \cdot 7 \\
36 \cdot 1 \pm 3 \cdot 4 \\
48 \cdot 9 \pm 4 \cdot 9 \\
45 \cdot 6 \pm 3 \cdot 2 \\
41 \cdot 7 \pm 1 \cdot 3 \\
40 \cdot 5 \pm 0 \cdot 7\end{array}$ & $\begin{array}{r}10 \\
4 \\
10 \\
4 \\
10 \\
4\end{array}$ & $\begin{array}{l}38 \cdot 7 \pm 1 \cdot 7 \\
39 \cdot 6 \pm 3 \cdot 3 \\
47 \cdot 5 \pm 5 \cdot 1 \\
50 \cdot 7 \pm 3 \cdot 9 \\
42 \cdot 3 \pm 2 \cdot 8 \\
44 \cdot 4 \pm 1 \cdot 7\end{array}$ & $\begin{array}{l}+1.7 \\
+3.5 \\
-1.4 \\
+5 \cdot 1 \\
+0.6 \\
+3.9\end{array}$ & $\begin{array}{l}>0.05 \\
>0.10 \\
>0.30 \\
>0.05 \\
>0.30 \\
<0.01\end{array}$ & $\begin{array}{l}\text { Ns } \\
\text { Ns } \\
\text { Ns } \\
\text { Ns } \\
\text { Ns } \\
\text { S }\end{array}$ \\
\hline J.B.D. & $\begin{array}{l}\text { Legs } \\
\text { Arms } \\
\text { Sens }\end{array}$ & $\begin{array}{l}\mathbf{A} \\
\mathbf{B} \\
\mathbf{B}\end{array}$ & $\begin{array}{r}12 \\
4 \\
11 \\
4 \\
10 \\
4\end{array}$ & $\begin{array}{l}19 \cdot 7 \pm 3 \cdot 3 \\
18 \cdot 9 \pm 2 \cdot 7 \\
42 \cdot 4 \pm 3 \cdot 0 \\
40 \cdot 6 \pm 3 \cdot 1 \\
40 \cdot 5 \pm 3 \cdot 5 \\
39 \cdot 7 \pm 2 \cdot 1\end{array}$ & $\begin{array}{r}10 \\
4 \\
18 \\
4 \\
18 \\
4\end{array}$ & $\begin{array}{l}21 \cdot 1 \pm 4 \cdot 5 \\
25 \cdot 4 \pm 3 \cdot 2 \\
43 \cdot 6 \pm 3 \cdot 6 \\
46 \cdot 8 \pm 5 \cdot 1 \\
44 \cdot 2 \pm 2 \cdot 3 \\
43 \cdot 8 \pm 3 \cdot 8\end{array}$ & $\begin{array}{l}+1 \cdot 4 \\
+6 \cdot 5 \\
+1 \cdot 2 \\
+6 \cdot 2 \\
+3 \cdot 7 \\
+4 \cdot 1\end{array}$ & $\begin{array}{l}>0.20 \\
<0.025 \\
>0.15 \\
>0.05 \\
<0.0025 \\
>0.05\end{array}$ & $\begin{array}{l}\text { Ns } \\
\text { S } \\
\text { Ns } \\
\text { Ns } \\
\text { S } \\
\text { Ns }\end{array}$ \\
\hline & & & $\mathrm{Mg}$ & free: $\mathrm{Ca} 3$ & $\mathbf{M g}$ & olus: Ca3 & & & \\
\hline C.McL. & $\begin{array}{l}\text { Legs } \\
\text { Arms } \\
\text { Sens }\end{array}$ & $\begin{array}{l}\mathbf{B} \\
\mathrm{N} \\
\mathrm{N}\end{array}$ & $\begin{array}{r}6 \\
4 \\
17 \\
4 \\
16 \\
4\end{array}$ & $\begin{array}{l}40 \cdot 3 \pm 3 \cdot 6 \\
42 \cdot 3 \pm 2 \cdot 0 \\
50 \cdot 4 \pm 3 \cdot 9 \\
54 \cdot 5 \pm 2 \cdot 9 \\
40 \cdot 5 \pm 3 \cdot 2 \\
39 \cdot 0 \pm 1 \cdot 7\end{array}$ & $\begin{array}{r}9 \\
3 \\
20 \\
4 \\
21 \\
4\end{array}$ & $\begin{array}{l}38 \cdot 8 \pm 4 \cdot 5 \\
36 \cdot 7 \pm 0 \cdot 3 \\
49 \cdot 4 \pm 4 \cdot 7 \\
48 \cdot 2 \pm 4 \cdot 8 \\
39 \cdot 7 \pm 3 \cdot 4 \\
41 \cdot 9 \pm 2 \cdot 0\end{array}$ & $\begin{array}{l}-1.5 \\
-5.6 \\
-1.0 \\
-6.3 \\
-0.8 \\
+2.9\end{array}$ & $\begin{array}{l}>0.25 \\
<0.01 \\
>0.20 \\
<0.05 \\
>0.20 \\
>0.05\end{array}$ & $\begin{array}{l}\text { Ns } \\
\text { S } \\
\text { Ns } \\
\text { S } \\
\text { Ns } \\
\text { Ns }\end{array}$ \\
\hline
\end{tabular}

* Overall mean given first, mean of last four results in phase given second.

$\mathbf{A}=$ abnormal, $\mathbf{B}=$ borderline, $\mathbf{N}=$ normal, $\mathrm{S}=$ significant, $\mathrm{Ns}=$ not significant.

patient L.R. during the second magnesium-plus phase (phase 3) that measurements taken at the beginning and end of that phase are shown separately, there being an interval in her case of four months between the measurements at the beginning and at the end of the phase. Corresponding comparisons of mean nerve conduction velocities in the presence and absence of magnesium in $\mathrm{Ca}-3$ solution are shown in Table 4.

In Table 5 the significance of the differences in the borderline group is shown individually, along with the significance of the sign test ${ }^{1}$ applied to all the groups and overall. The individual changes for each nerve were often small numerically, of the order of 0.5 to 5.0 $\mathrm{m} / \mathrm{sec}$ generally. Since the standard deviation of the method used is relatively high (of the order of \pm 2.0 to $3.0 \mathrm{~m} / \mathrm{sec}$ ) the level of statistical significance reached in the individual comparisons was not always marked, though $\mathrm{P}$ was nevertheless often $<0 \cdot 05$. Assessing the direction

$$
1 \quad x^{2}=\frac{(a-b-1)^{2}}{a+b}
$$

where $a=$ number of times magnesium-free $>$ magnesium-plus $b=$ number of times magnesium-free $<$ magnesium-plus the null hypothesis being that $a=b$. of change by the sign test $\left(\chi^{2}\right)$ for one degree of freedom, and assuming $\pm 2.0 \mathrm{~m} / \mathrm{sec}$ as no change, showed that the increased velocities on magnesium-free dialysis were highly significant, both within each group and overall $(\mathrm{P}<0.0005)$. Thus the increased velocities observed on magnesium-free dialysis and the deterioration on magnesium-plus dialysis occurred too often to be attributable to the operation of chance.

\section{DISCUSSION}

PLASMA MAGNeSIUM Hypermagnesaemia has long been associated with renal failure (Barker, Elkington, and Clark, 1959; Randall, Cohen, Spray, and Rossmeisl, 1964), although more recent reports have tended to draw attention to cases of chronic renal failure where plasma magnesium levels were normal or low (Clarkson, Warren, McDonald, and de Wardener, 1965 and 1967).

Although not apparently 'high' at first glance, it must be accepted that a dialysate magnesium concentration of $1.5 \mathrm{~m}$-equiv/l. augmented by 0.1 to 0.2 m-equiv/l. from tap water, is appreci- 
TABLE 5

SIGNIFICANCE OF DIFFERENCES IN NERVE CONDUCTION VELOCITY SHOWN IN TABLES 3 AND 4 (BORDERLINE GROUP) WITH THE OVERALL SIGNIFICANCES FOR ALL GROUPS

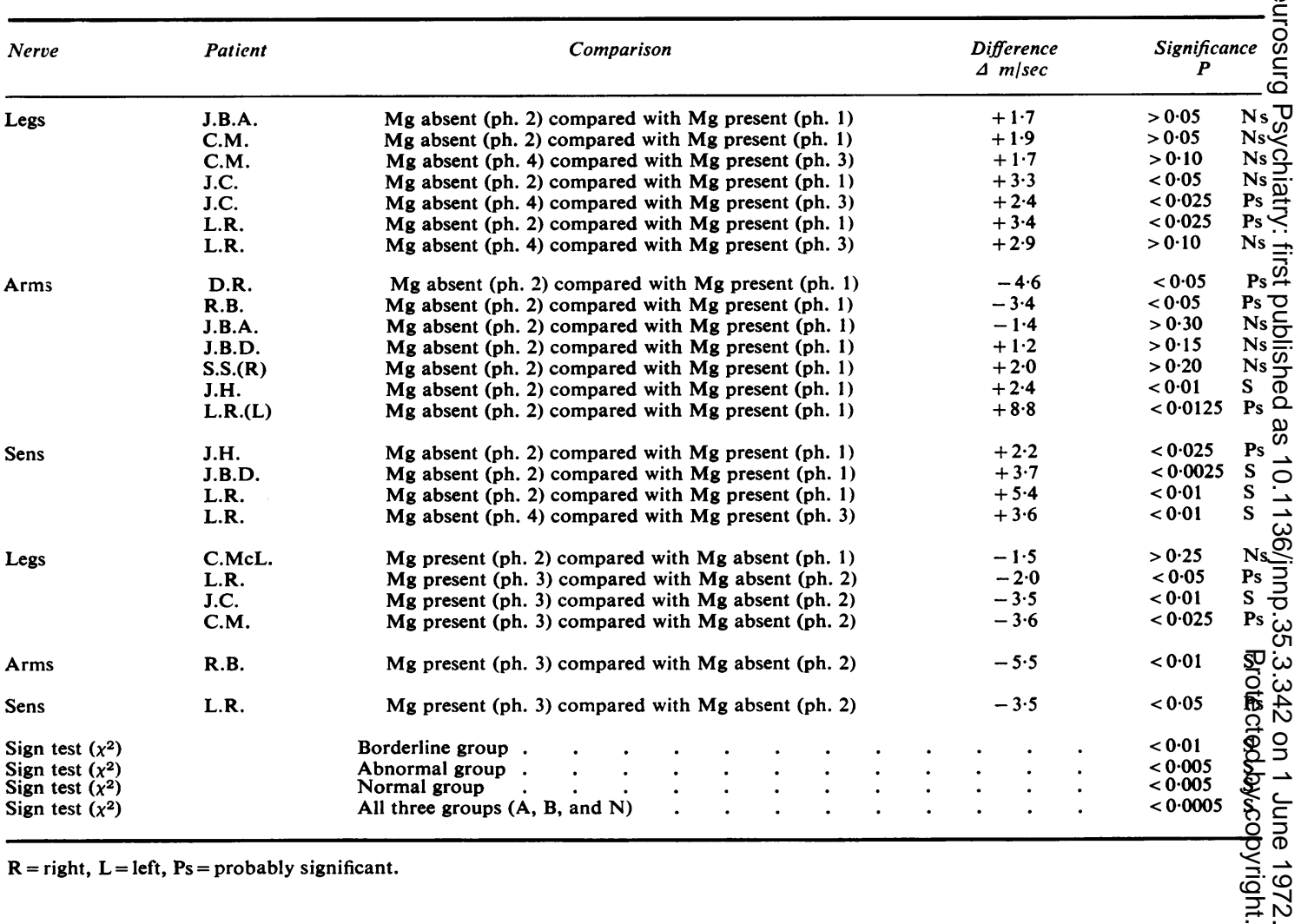

ably higher than the concentration of diffusable magnesium in normal plasma ( $1.27 \mathrm{~m}$-equiv/1.). This is likely to result in a progressive build-up of magnesium within body-fluids after a period of time (Ogden and Holmes, 1966). Robson (1968) has similarly found a progressive increase in plasma magnesium concentrations during the first two years of RDT but his results indicated that the plasma magnesium increase reached a plateau (at about $3.5 \mathrm{~m}$-equiv/l.) during the third year of treatment. Posen and Kaye (1967) and Coburn, Popovtzer, Massry, and Kleeman (1969) have also stressed the occurrence of hypermagnesaemia in patients on RDT and have similarly pointed to the dialysate magnesium as a contributory feature, over and above the natural consequences of the renal failure itself. In Dundee, the normal to low normal levels between which the patients fluctuate when on magnesium-free dialysis have been maintained over prolonged periods of time without further progressive decrease, and have appeared to be unassociated with any ill-effects. Stewart, Neale, $\stackrel{\mathbb{Q}}{\varrho}$ and Blomfield (1969) have described similar $\overrightarrow{\vec{B}}$ results with low magnesium-containing dialysis- 3 fluid $(0.5 \mathrm{~m}$-equiv/l.). Like us, they found no clinical ill-effects.

NEUROPATHY IN REGULAR DIALYSIS TREATMENT $\frac{0}{3}$ Clinical features The common occurrence of neuropathy in patients with chronic renal failure $\frac{\rho}{3}$ is well recognized (Preswick and Jeremy, 1964), both in non-dialysed (Coomes, Berlyne, and Shaw, 1966; Hollinrake and Thomas, 1968; van $\frac{D}{0}$ der Most van Spijk, Dijkstra, and Jennekens, 1969) and in dialysed patients (Liberson, $\sigma$ Gratzer, and Zalis, 1969). Heron, Konotey- $N$ 
Ahulu, Shaldon, and Thomas (1965) found no improvement in the neuropathy of patients with renal failure, after the institution of RDT. Although Funck-Brentano (1966) also noted further deterioration during RDT, Shaldon's group believe that such deterioration is only a sign of inadequate dialysis and that with efficient dialysis treatment, neuropathy will improve (Konotey-Ahulu, Baillod, Comty, Heron, Shaldon, and Thomas, 1965). Similarly Jebsen, Tenckhoff, and Honet (1967) actually advocate the serial measurement of nerve conduction velocities as an 'objective and sensitive guide to the adequacy of dialysis treatment'. Experience in Dundee does not support the above recommendation of Jebsen and his colleagues, nor do the results of Versaci, Olsen, McMain, Nakamoto, and Kolff (1964). The return of clinical good health, or at least of a sense of well-being as a result of RDT has not noticeably coincided with improvement in nerve conduction velocities in the patients studied.

Basically the neuropathy described in renal failure has affected peripheral nerves (Dyck, Johnson, Lambert, and O'Brien, 1971). Nielsen (1967) found a predominance of sensory changes in those patients who did show clinical evidence of the neuropathy, and he wrote in terms of a generalized defect, involving both slow- and fast-conducting sensory nerve fibres. Decreases in motor nerve conduction velocities have also been described (Heron, Konotey-Ahulu, Shaldon, and Thomas, 1965; Versaci et al., 1964; van der Most van Spijk et al., 1969). Often decreased motor nerve conduction velocities are found without any clinical evidence of neuropathy (Versaci et al., 1964; Stewart, Fleming, Anderson, Lenman, and Jamieson, 1967). Van der Most van Spijk et al. (1969) located a defect on all the $\alpha$-motor fibres of the N. peroneus profundus.

Asbury, Victor, and Adams (1963) have shown that the most striking pathological change in uraemic neuropathy is axonal degeneration. The later studies of Hollinrake and Thomas (1968) and of Dyck et al. (1971) showed that many nerve fibres showed demyelination, characteristically paranodal in distribution, in addition to axonal changes. The presence of demyelination is of interest in view of the marked slowing of conduction velocity observed in many of the patients, but this particular feature may not be relevant to the influence of magnesium.

Although only two of the patients described here (J.B.D. and R.B.) had any clinical evidence of neuropathy, all had decreased motor nerve conduction velocities in the common peroneal nerve. It is striking that the objective defect in some of these patients was so extensive without clinical signs being evident. In fact the predominant clinical symptoms when present were, as in Nielsen's patients, sensory not motor.

Significance Honet and colleagues (1968) have shown that the variability of repeated nerve conduction velocity measurements made in normal subjects over prolonged periods of time can be as much as $\pm 5.8 \mathrm{~m} / \mathrm{sec}$ (SD). The variability of repeated readings of the same photographic record on different occasions was between \pm 2.0 and $\pm 3.0 \mathrm{~m} / \mathrm{sec}$. Careful measurement technique could reduce the maximum variation to $\pm 3.3 \mathrm{~m} / \mathrm{sec}$ (SD) which is similar to what we have found in practice. It must be admitted that the improvements in conduction velocities described here are of a similar order of magnitude. When the observed changes are small and the errors of reproducibility of the method comparatively large, one must be critical of the validity of the results. Nevertheless, it is in this kind of situation that statistical methods are of the most value. The finding once or twice of improved nerve conduction velocities under one set of conditions (magnesium-free dialysis) could be due to chance, but the repeated finding of the improvements coupled with the regularly repeated decrease when magnesium was restored to the dialysis-fluid, tended to dispel doubts even when the individual change was small. The high significance of these recurring findings is shown by the sign test $(P<0.0005)$. Furthermore, a change that would require many repeated observations to become statistically significant, may yet represent a highly significant change physiologically.

Effect of time One might think that the improvements in nerve conduction during magnesium-free dialysis were only a consequence of the increasing length of time on RDT. Against this viewpoint one must put the fact 
TABLE 6

ASSESSMENT OF TIME FACTOR

\begin{tabular}{|c|c|c|c|c|c|c|c|c|c|c|c|}
\hline \multirow[t]{2}{*}{ Patient } & \multirow{2}{*}{$\begin{array}{c}\text { Months } \\
\text { on } R D T \\
\text { on } \\
\text { beginning } \\
\text { Mg-plus } \\
\text { after } \\
\text { Mg-free } \\
\text { (no.) }\end{array}$} & \multirow{2}{*}{$\begin{array}{c}\text { Dialyses } \\
\text { on } \\
\text { beginning } \\
\text { Mg-plus } \\
\text { after } \\
\text { Mg-free } \\
\text { (no.) }\end{array}$} & \multirow{2}{*}{$\begin{array}{c}\text { Months } \\
\text { on } \\
\text { Mg-plus } \\
\text { (no.) }\end{array}$} & & \multirow{2}{*}{$\begin{array}{c}\text { NCV } \\
\text { changes } \\
\text { during } \\
\text { Mg-plus } \\
\text { dialysis }\end{array}$} & \multicolumn{2}{|c|}{ First $N C V$ result } & \multicolumn{2}{|c|}{ Last $N C V$ result } & \multirow{2}{*}{$\begin{array}{c}\text { Months } \\
\text { on } \\
\text { Mg-free } \\
\text { (total } \\
\text { no.) }\end{array}$} & \multirow{2}{*}{$\begin{array}{c}\text { Change } \\
\text { in } \\
N C V\end{array}$} \\
\hline & & & & & & $\begin{array}{c}\text { Months } \\
\text { on } \\
R D T \\
\text { (no.) }\end{array}$ & $\mathrm{m} / \mathrm{sec}$ & $\begin{array}{c}\text { Months } \\
\text { on } \\
R D T \\
\text { (no.) }\end{array}$ & $\mathrm{m} / \mathrm{sec}$ & & \\
\hline C.McL. & 5 & 62 & 11 & $\begin{array}{l}\mathbf{L} \\
\mathbf{A} \\
\mathbf{S}\end{array}$ & $\begin{array}{l}\text { Deteriorated } \\
\text { Deteriorated } \\
\text { Deteriorated }\end{array}$ & 0 & $\begin{array}{l}39 \cdot 1 \\
51 \cdot 0 \\
49 \cdot 1\end{array}$ & 16 & $\begin{array}{l}36 \cdot 5 \\
51 \cdot 0 \\
42 \cdot 0\end{array}$ & 5 & $\begin{array}{l}\text { Deterioratec } \\
\text { No change } \\
\text { Deteriorated }\end{array}$ \\
\hline C.M. & 7 & 68 & 5 & $\begin{array}{l}\mathbf{L} \\
\mathbf{A} \\
\mathbf{S}\end{array}$ & $\begin{array}{l}\text { Deteriorated } \\
\text { No change } \\
\text { Deteriorated }\end{array}$ & $<1$ & $\begin{array}{l}44 \cdot 1 \\
51 \cdot 3 \\
43 \cdot 0\end{array}$ & 13 & $\begin{array}{l}43 \cdot 9 \\
52 \cdot 7 \\
38 \cdot 8\end{array}$ & 6 & $\begin{array}{l}\text { No change } \\
\text { Improved } \\
\text { Deterioratec }\end{array}$ \\
\hline J.C. & 8 & 73 & 8 & $\begin{array}{l}\mathbf{L} \\
\mathbf{A} \\
\mathbf{S}\end{array}$ & $\begin{array}{l}\text { Deteriorated } \\
\text { Deteriorated } \\
\text { Deteriorated }\end{array}$ & 4 & $\begin{array}{l}40 \cdot 4 \\
59 \cdot 2 \\
43 \cdot 3\end{array}$ & 28 & $\begin{array}{l}44 \cdot 6 \\
56 \cdot 0 \\
50 \cdot 0\end{array}$ & 15 & $\begin{array}{l}\text { Improved } \\
\text { Deterioratec } \\
\text { Improved }\end{array}$ \\
\hline L.R. & 7 & 77 & 9 & $\begin{array}{l}\mathbf{L} \\
\mathbf{A} \\
\mathbf{S}\end{array}$ & $\begin{array}{l}\text { Deteriorated } \\
\text { Deteriorated } \\
\text { Deteriorated }\end{array}$ & 4 & $\begin{array}{l}38 \cdot 7 \\
49 \cdot 3 \\
36 \cdot 4\end{array}$ & 27 & $\begin{array}{l}42 \cdot 9 \\
54 \cdot 1 \\
44 \cdot 6\end{array}$ & 12 & $\begin{array}{l}\text { Improved } \\
\text { Improved } \\
\text { Improved }\end{array}$ \\
\hline R.B. & 10 & 88 & 1 & $\begin{array}{l}\mathbf{L} \\
\mathbf{A} \\
\mathbf{S}\end{array}$ & $\begin{array}{l}\text { Deteriorated } \\
\text { Deteriorated } \\
\text { Deteriorated }\end{array}$ & $3+1$ & $\begin{array}{c}25 \cdot 2 \\
41 \cdot 8 \\
\text { None ev. }\end{array}$ & 11 & $\begin{array}{c}\text { None ev. } \\
32 \cdot 2 \\
32 \cdot 0\end{array}$ & 6 & $\begin{array}{c}\text { Deteriorated } \\
\text { Deteriorated } \\
-\end{array}$ \\
\hline
\end{tabular}

that velocities decreased during the second period of magnesium-containing dialysis (phase 3) despite the continuing increase in time on RDT, and increased again only on reverting to dialysis without magnesium.

In Table 6 the evidence against a time factor being responsible for the improvement is marshalled. The number of months on dialysis with magnesium, after an established improvement in velocities during magnesium-free dialysis, varied from one to 11 months, and in every case there was deterioration over the period of magnesium-plus dialysis. The first and last NCV results for each patient are also compared, together with a note of the number of months on dialysis at the time of the measurements. Those who showed improvement between the first and last measurements had been dialysed for the longest periods without magnesium (12 and 15 months respectively) and the patient with the least number of months on magnesium-free dialysis (five months) showed most deterioration.

Subsequent studies Posen and Kaye (1967) noticed that clinical signs of neuropathy were absent in their patients on RDT, and attributed this to a possible protection by magnesium in view of the high magnesium content of Montrea tap water and the resultant hypermagnesaem They did not, however, report the results of a迎y actual measurements of nerve conduction volocity. Subsequent studies (Hollinrake, Thom Wills, and Baillod, 1970) have effectively d proved this possibility by showing that patients with clinical evidence of neuropathy had no? tendency towards lower plasma magnesiums concentrations. Indeed the reverse was true, such findings being more in accord with the experi ence in Dundee.

Robson (1968) found no correlation between $\overrightarrow{\vec{B}}$ plasma magnesium and 'uraemic neuropathy', pointing out that plasma magnesium concentra tions tended to increase with increasing length of time on RDT in his patients, whereas the neuropathy, at least after 20 months on dialysis tended to improve. However, Robson (1968) didB. not actually describe the effects on the neuropathy of low magnesium dialysis, reporting only his experience with dialysate containing 1.50 m-equiv/l. of magnesium. Similarly there was no correlation, either positive or negative, between? the prevalence of neuropathy and the magnesiumn content of the dialysate in the latest European survey of the results of RDT (Drukker, Haagsma- 
Schouten, Alberts, and Spoek, 1969). However this is not as precise an approach as longitudinal studies on individual patients, each serving as his own control.

Neurological effects, in particular sensory symptoms, have been noted during the accidental use of dialysis fluid containing high concentrations of magnesium (Drukker, 1968; Govan, Porter, Look, Dixon, and Trafford, 1968).

There is also the possibility that a positive correlation between plasma magnesium concentrations and neuropathy arises when RDT is less than adequate, but in conditions of fully adequate dialysis, the effect of changing magnesium concentrations on the neuropathy is lessened. The applicability of this possibility would imply that RDT in the Dundee Unit was in some sense inadequate. Although in most cases a return of patient well-being was seen, it is admitted that lack of space and staff have meant that patients have occasionally been dialysed for periods of time which fell short of the 'ideal'.

Hollinrake et al. (1970) have also examined the relationship between neuropathy and plasma magnesium levels during RDT. Although their findings failed to reach the level of statistical significance of the results reported here the trend of the changes they did observe was concordant with our observations. Their experiments were not directly comparable with the original Dundee series in every feature, in that they measured the nerve conduction velocities in the median and lateral popliteal nerves before and after a four month period of magnesium-free dialysis in 10 patients, three of whom had overt clinical evidence of neuropathy. Although they did not find any change in the normal conduction velocities of the median nerve, they did record an increase comparable with our findings in the abnormal velocities recorded from the popliteal nerve after magnesium-free dialysis $(38.4 \mathrm{com}$ pared with $35 \cdot 2 \mathrm{~m} / \mathrm{sec}$ ). This increase fell short of statistical significance but nevertheless was approaching the level of probable significance (cited as $\mathrm{P}>0.05$; however, as recalculated from the authors' data $P>0.05$ but $<0 \cdot 10$ ). Repeated observations of this kind, although not individually statistically significant, would materially support the positive relationship which we have postulated.
It may be relevant that the hypermagnesaemia seen in the London patients (Hollinrake et al., 1970) while on magnesium-containing dialysis was less marked than that in the Dundee patients (pre-dialysis mean plasma magnesium levels ( \pm SD) of $1.75 \pm 0.41 \mathrm{~m}$-equiv/l. in London compared with $2.90 \pm 0.26 \mathrm{~m}$-equiv/l. in Dundee). This is likely to be due both to dietary differences and to deionization of the London water supply for dialysis.

Unfortunately, Hollinrake and colleagues did not record the magnesium concentration of their magnesium-containing dialysate. Their patients' mean plasma levels $( \pm S D)$ on magnesium-free dialysis were more comparable with, though still lower than, those usually seen in Dundee $(1.52 \pm 0.50 \mathrm{~m}$-equiv/l. pre-dialysis and 0.75 m-equiv/l. post-dialysis, no SD given in London, compared with our level of $1.96 \pm 0.28 \mathrm{~m}$-equiv/l. pre-dialysis and $1 \cdot 24 \pm 0.22 \mathrm{~m}$-equiv/l. postdialysis). The lack of significant hypermagnesaemia in the London patients meant that the extent of the plasma magnesium alteration on changing from magnesium-containing to magnesium-free dialysis was less. In these circumstances, as the authors admit, four months is perhaps not long enough to produce a statistically significant change in nerve conduction velocities. Hollinrake and his colleagues mentioned that the neurological state of the patients did not deteriorate in any way during the magnesium-free dialysis and no new neuropathy occurrec

Hollinrake et al. (1970) also measured the pre-dialysis plasma magnesium concentrations of 34 patients on RDT, eight of whom had clinical evidence of neuropathy, and found that, although the difference was again not statistically significant $(\mathrm{P}>0.05$ but $<0.01)$, the eight patients with neuropathy did have a higher mean plasma magnesium concentration, $1.99 \pm 0.50$ m-equiv/l. compared with $1 \cdot 67 \pm 0.36 \mathrm{~m}$-equiv/l. in those without neuropathy. Although the authors considered that they had not substantiated the claim for a positive relationship between neuropathy and the magnesium level, it can be seen that their results do not directly conflict with those described here or in the preliminary communication (Stewart et al., 1967). 
Phylogenetic comparisons A brief summary of nerve conduction velocities seen in present-day animals, taken as representative of various stages in the evolutionary tree, and of the concurrent development of magnesium homoeostasis and lowered extracellular magnesium levels, shows an interesting correlation, with relevance to the theories suggested by the results described. Although other factors such as diameter of fibre, myelination or lack of myelination, extent of differentiation in the central nervous system and environmental temperature play an important part in determining the rate of conduction velocity (Schmidt-Nielsen, 1960; Yapp, 1970), within the broad limits of these other variables, a possible correlation with the extracellular fluid magnesium concentration can be seen, showing that as magnesium levels have decreased, nerve conduction velocities have increased (Fig. 3). This could represent a purely

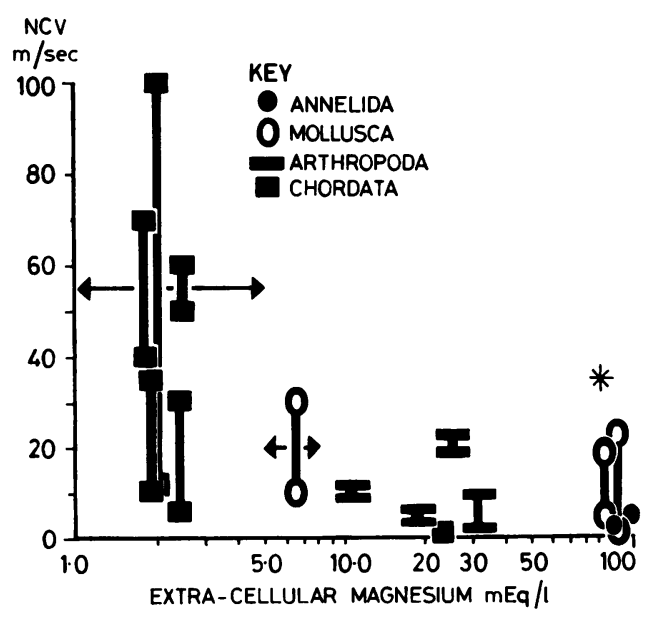

FIG. 3. Phylogenetic relationships between extracellular magnesium concentrations and nerve conduction velocities representative of various phyla. The ${ }^{*}$ indicates the squid giant axon.

fortuitous concurrence and non-related development within the timescale of evolution, but the possibility that it is not entirely fortuitous is suggested by the experimental results summarized in Fig. 2, where within the same individual a decrease in plasma magnesium concentration coincides with an increased rate of conduction $\stackrel{\mathbb{0}}{\stackrel{5}{\circ}}$ velocity, particularly in those nerves where $\frac{O}{Z}$ velocity has become slower than normal, and $\frac{\mathrm{o}}{\mathrm{C}}$ vice versa. Magnesium may therefore be an evolutionary factor influencing the conduction of the more rapidly conducting myelinated $\overline{0}$ fibres.

Possible mechanisms of involvement The relationship of neuropathy to the multifactorial processes involved in the uraemia of patients with $\Rightarrow$ renal failure is obviously complex. Lack of recognized dialysable vitamins is not now con-듬 sidered as an important factor (Funck-Brentano $\overline{\bar{n}}$ and Vantelon, 1963). The continued loss of some other unknown but dialysable metabolite has been postulated as a possible factor in the pathogenesis of neuropathy during RDT (Heg-. strom, Murray, Pendras, Burnell, and Scribner, $\vec{\omega}$ 1962). Similarly an excess of some unknown undialysable substance could initiate the deterioration (Lancet, 1971). Szegedy, Berényi, and $\dot{\omega}_{\omega}$ Csata (1968) believe that the neurological is complications result from a 'cerebral oxygen $\bar{\theta}-\omega$ tion disorder'.

In this confusing situation, the possibge? mechanisms through which changes in extracellular magnesium concentrations could igfluence the rate of conduction of nerve impulsegs ${ }^{\Phi}$ remain to be elucidated. We are not claimiage $\overrightarrow{0}$ that high extracellular magnesium levels haze? primarily caused the neuropathy but the need to explain the influence of magnesium once neuro-s pathy has become evident remains. It is of interest that phenytoin, which like magnesium isö a membrane stabilizer, can cause neuropathyo with decreased conduction velocities (Lovelace $\overrightarrow{0}$ and Horwitz, 1968).

There exists a body of in vitro studies linking the concentrations of calcium and magnesium in the incubation medium to the propagation of nerve impulses, mostly using the squid axon (Frankenhaeuser and Hodgkin, 1957; Franken haeuser and Meves, 1958). Nerves stored in solutions of high magnesium and low calcium concentrations do not survive well (Franken-o haeuser and Hodgkin, 1957). The presence of calcium is necessary for the conduction of the impulse (Tasaki, Watanabe, and Lerman, 1967) and as far as the axon fibre surface itself is concerned magnesium has the same physio 
logical effect as calcium, only a higher concentration of magnesium is required for the same effect (Mg: $\mathrm{Ca}$ as 2.4:1, Frankenhaeuser and Meves, 1958). High concentrations of either calcium or magnesium increase the threshold of excitability (Frankenhaeuser and Meves, 1958) and inhibit sodium-potassium transfer. During excitation, the decrease in potential difference across the membrane has been shown to vary with the concentration of calcium and magnesium in the external medium (Hodgkin, 1964). Blaustein and Goldman (1968) mentioned that both cations appear to be bound to the membrane, and that their relative effects on conductance may depend on their relative binding constants. These in vitro findings are in general accord with lowered nerve conduction velocities associated with hypermagnesaemia.

Abood (1966) envisages the nerve-membrane as consisting of phospholipid lipoprotein complexes linked to ATP-magnesium-enzyme complexes by chelated calcium ions. His hypothesis, on the role of magnesium-activated ATP-ase in the initiation of the alterations in nerve membrane structure which are thought to precede depolarization, further substantiates the proposition that in vivo changes in extracellular magnesium concentrations could well have an effect on the conduction of impulses along nerves. The presence of high magnesium concentrations could inhibit the process by altering the ratio of calcium and magnesium bound to the ATP complex, or by stabilizing the ATP-enzyme complex and decreasing the rate of hydrolysis.

It is perhaps relevant at this point to emphasize that, although calcium and magnesium are antagonistic at sites of stimulus-secretion coupling (Douglas, 1968) and at neuromuscular endplates, where transmission by chemical substances is involved (Castillo and Engbaek, 1954; Katz and Miledi, 1965) the two divalent cations are synergistic as far as their effects on electrical transmission along excitable membranes are concerned. The clinical effects of chronic hypermagnesaemia, coinciding with chronic hypocalcaemia on synaptic transmission in vivo, are conjectural and may well have indirect effects on the rates of axonal transmission when the influence is a protracted one.

We consider that the results described here may represent a link between in vitro and in vivo investigations into the effects of magnesium on nerve impulse propagation. In vitro studies have produced detailed information on the concentration of divalent cations required in the external medium. We have shown that detectable changes in conduction velocity can be demonstrated in vivo within the limits of pathological alterations in cation concentrations in extracellular fluid.

The described effects on nerve conduction velocity are further evidence that magnesium has a role to play in membrane phenomena generally. This action of magnesium is possibly dependent on its binding capacity to various membrane proteins. In excitable membranes in particular the specific proteins involved in magnesium and calcium binding are likely to be functionally linked to the mechanisms for the propagation of nerve impulses. The progressive decrease in extracellular magnesium concentrations which has taken place throughout evolution, which runs concurrently with the development of more complex nervous systems and faster nerve-conduction rates, may also reflect the importance of the association between magnesium and the functional activity of excitable membranes.

We wish to thank the technicians of the Department of Medicine for expert technical skill and care during the many estimations that this investigation involved.

\section{REFERENCES}

Abood, L. G. (1966). Interrelationships between phosphates and calcium in bioelectric phenomena. International Review of Neurobiology, 9, 223-261.

Asbury, A. K., Victor, M., and Adams, R. D. (1963) Uremic polyneuropathy. Archives of Neurology, 8, 413-428.

Barker, E. S., Elkinton, J. R., and Clark, J. K. (1959). Studies of the renal excretion of magnesium in man. Journal of Clinical Investigation, 38, 1733-1745.

Blaustein, M. P., and Goldman, D. E. (1968). The action of certain polyvalent cations on the voltage-clamped lobster axon. Journal of General Physiology, 51, 279-291.

Castillo, J. del, and Engbaek, L. (1954). The nature of the neuromuscular block produced by magnesium. Journal of Physiology, 124, 370-384.

Clarkson, E. M., McDonald, S. J., de Wardener, H. E., and Warren, R. (1965). Magnesium metabolism in chronic renal failure. Clinical Science, 28, 107-115.

Clarkson, E. M., Warren, R. L., McDonald, S. J., and de Wardener, H. E. (1967). The effect of a high intake of calcium on magnesium metabolism in normal subjects and patients with chronic renal failure. Clinical Science, 32, 11-18. 
Coburn, J. W., Popovtzer, M., Massry, S. G., and Kleeman, C. R. (1969). The physicochemical state and renal handling of divalent ions in chronic renal failure. Archives of Internal Medicine, 124, 302-311.

Coomes, E. N., Berlyne, G. M., and Shaw, A. B. (1966). Incidence of neuropathy in non-dialysed chronic renal failure patients. In Proceedings of the Second Conference on Renal Failure and Replacement of Renal Function, Newcastle-upon-Tyne, 1965. Excerpta Medica Foundation International Congress Series No. 103, 1966. Proceedings of the European Dialysis and Transplant Association, 2 , 133-137. Excerpta Medica: Amsterdam.

Douglas, W. W. (1968). Stimulus-secretion coupling: the concept and clues from chromaffin and other cells. British Journal of Pharmacology, 34, 451-474.

Drukker, W. (1968). The hard water syndrome: a potential hazard during regular dialysis treatment. In Dialysis and Renal Transplantation. Proceedings of the Sixth Conference, Stockholm, 1969. Proceedings of the European Dialysis and Transplant Association, 5, 284-287. Pitman: London.

Drukker, W., Haagsma-Schouten, W. A. G., Alberts, C., and Spoek, M. G. (1969). Report on regular dialysis treatment in Europe V, 1969. In Proceedings of the Fifth Conference, Dublin, 1968, Excerpta Medica Foundation International Congress Series No. 1791, 1969. Proceedings of the European Dialysis and Transplant Association, 6, 99-108.

Dyck, P. J., Johnson, W. J., Lambert, E. H., and O'Brien, P. C. (1971). Segmental demyelination secondary to axonal degeneration in uremic neuropathy. Mayo Clinic Proceedings, 46, 400-431.

Fleming, L. W., and Stewart, W. K. (1966). The effect of the atomiser on the estimation of magnesium by atomic absorption spectrophotometry. Clinica Chimica Acta, 14, 131-134.

Frankenhaeuser, B., and Hodgkin, A. L. (1957). The action of calcium on the electrical properties of squid axons. Journal of Physiology, 137, 218-244.

Frankenhaeuser, B., and Meves, H. (1958). The effect of magnesium and calcium on the frog myelinated nerve fibre. Journal of Physiology, 142, 360-365.

Funck-Brentano, J. L. (1966). In Discussion: Calcium deposits in patients treated by chronic haemodialysis. In Proceedings of the Second Conference on Renal Failure and Replacement of Renal Function, Newcastle-upon-Tyne, 1965, Excerpta Medica Foundation International Congress Series No. 103, 1966. Proceedings of the European Dialysis and Transplant Association, 2, 96-97, 143.

Funck-Brentano, J. L., and Vantelon, J. (1963). Les polynévrites des urémies chroniques traitées par hémodialyses répétées. Comptes Rendus du Deuxième Congrès International de Néphrologie, Prague, 1963. International Congress Series No. 78, 173-175. Excerpta Medica Foundation: Amsterdam.

Govan, J. R., Porter, C. A., Cook, J. G. H., Dixon, B., and Trafford, J. A. P. (1968). Acute magnesium poisoning as a complication of chronic intermittent haemodialysis. British Medical Journal, 2, 278-279.

Hegstrom, R. M., Murray, J. S., Pendras, J. P., Burnell, J. M., and Scribner, B. H. (1962). Two years' experience with periodic hemodialysis in the treatment of chronic uremia. Transactions of the American Society for Artificial Internal Organs, 8, 266-280.

Heron, J. R., Konotey-Ahulu, F. I. D., Shaldon, S., and Thomas, P. K. (1965). Nerve conduction in chronic renal failure treated by dialysis. In Proceedings of the Second Conference on Renal Failure and Replacement of Renal Function, Newcastle-upon-Tyne, 1965. Excerpta Medica Foundation International Congress Series No. 103, 1966, Proceedings of the European Dialysis and Transplant Association, 2, 138-140.
Hodgkin, A. L. (1964). The Conduction of the Nervous Impulse. Sherington Lectures, pp. 15, 18, 30-46. Liverpool Uni-ō versity Press: Liverpool.

Hollinrake, K., and Thomas, P. K. (1968). Electrical and $Z$ morphological observations on uraemic neuropathy (abstract). Electroencephalography and Clinical Neuro-O physiology, 25, 398-399.

Hollinrake, K., Thomas, P. K., Wills, M. R., and Baillod R. A. (1970). Observations on plasma magnesium levels in patients with uremic neuropathy under treatment bye periodic hemodialysis. Neurology (Minneapolis) 20, 939942.

Honet, J. C., Jebsen, R. H., and Perrin, E. B. (1968). Vari $\frac{\text { (196) }}{+}$ ability of nerve conduction velocity determinations innormal persons. Archives of Physical Medicine, 49, 650-654.

Jebsen, R. H., Tenckhoff, H., and Honet, J. C. (1967). Natural history of uremic polyneuropathy and effects of dialysis. New England Journal of Medicine, 277, 327-333.

Katz, B., and Miledi, R. (1965). The effect of calcium on acetylcholine release from motor nerve terminals. Pro-J ceedings of the Royal Society (Biology), 1618, 496-503.

Konotey-A hulu, F. I. D., Baillod, R., Comty, C. M., Heron, J. R., Shaldon, S., and Thomas, P. K. (1965). Effect of periodic dialysis on the peripheral neuropathy of end $\overrightarrow{0}$ stage renal failure. British Medical Journal, 2, 1212-1215.

Lancet (1971). Uraemic neuropathy and renal transplantation. Lancet, 2, 418-419.

Lenman, J. A. R., and Ritchie, A. E. (1970). Clinical Electro $\overline{\overline{7}}$ myography, pp. 15, 42-57. Pitman: London.

Liberson, W. T., Gratzer, M., and Zalis, A. W. (1969)? Electrodiagnostic indices in patients with renal dialysis (Abstract.) Electroencephalography and Clinical Neurb physiology, 27, 724.

Lovelace, R. E., and Horwitz, S. J. (1968). Peripheral neugिo pathy in long-term diphenylhydantoin therapy. Archive $\$ 05$ Neurology, 18, 69-77.

Nielsen, V. K. (1967). Sensory nerve conduction studiesginuraemic patients. In Dialysis and Renal Transplantatign $\complement_{\subseteq}$ Proceedings of the Fourth Conference, Paris, 1967. Excerota Medica Foundation International Congress Series No. 3 1968. Proceedings of the European Dialysis and Transp finto Association, 4, 279-284. Pitman: London.

Ogden, D. A., and Holmes, J. H. (1966). Changes in total and ultrafilterable plasma calcium and magnesium during hemodialysis. Transactions of the American Society for Artificial Internal Organs, 12, 200-204.

Posen, G. A., and Kaye, M. (1967). Magnesium metabolisn in patients on chronic haemodialysis. In Dialysis and Renaf Transplantation. Proceedings of the Fourth Conference Paris, 1967. Excerpta Medica Foundation International Congress Series No. 155, 1968. Proceedings of the Europea Dialysis and Transplant Association, 4, 224-228. Pitman? London.

Preswick, G., and Jeremy, D. (1964). Subclinical polyneuroo pathy in renal insufficiency. Lancet, 2, 731-732.

Randall, R. E., Jr., Cohen, M. D., Spray, C. C., Jr., anథ Rossmeisl, E. C. (1964). Hypermagnesemia in renal failure Annals of Internal Medicine, 61, 73-88.

Robson, J. S. (1968). Uraemic neuropathy. In Symposium Some Aspects of Neurology, pp. 74-84, Edited by R. $\vec{F}_{0}$ Robertson. Royal College of Physicians of Edinburgho Edinburgh.

Schmidt-Nielsen, K. S. (1960). Animal Physiology, p. 9o Prentice-Hall: Englewood Cliffs, N. J.

Stewart, J. H., Neale, F. C., and Blomfield, J. (1969) Magnesium and the haemodialysis patient. (Letter to Editor.) Lancet, 2, 798-799.

Stewart, W. K., Fleming, L. W., Anderson, D. C., Lenmar্ J. A. R., and Jamieson, D. G. (1967). Changes in plasma electrolytes and nerve-conduction velocities during chron 
haemodialysis without magnesium. In Dialysis and Renal Transplantation. Proceedings of the Fourth Conference, Paris, 1967. Excerpta Medica Foundation International Congress Series No. 155, 1968. Proceedings of the European Dialysis and Transplant Association, 4, 285-291. Pitman: London.

Szegedy, L., Berényi, M., and Csata, S. (1968). Complications in the nervous system under the influence of hemodialysis, attributable to changes of the serum-liquor electrolyte and pH levels. European Neurology, 1, 247-254.

Tasaki, I., Watanabe, A., and Lerman, L. (1967). Role of divalent cations in excitation of squid giant axons. American Journal of Physiology, 213, 1465-1474. van der Most van Spijk, D., Dijkstra, S., and Jennekens, F. G. I. (1969). Maximum conduction velocity and range of conduction velocity in motor fibres of the deep peroneal nerve in patients with chronic renal insufficiency. (Abstract.) Electroencephalography and Clinical Neurophysiology, 27, 715.

Versaci, A. A., Olsen, K. J., McMain, P. B., Nakamoto, S., and Kolff, W. J. (1964). Uremic polyneuropathy: and motor nerve conduction velocities. Transactions of the American Society for Artificial Internal Organs, 10, 328330.

Yapp, W. B. (1970). An Introduction to Animal Physiology, 3rd edn, pp. 145-146, 179, 181. Clarendon Press: Oxford. 